\section{INSURTECH - LEHETŐSÉG A PIACON VAGY VESZÉLY AZ ÜZLETRE?}

Wágner Máté (PwC, Senior aktuárius)

A szerzőnek a témában 2017. október 3-án jelent meg cikke a Világgazdaság folyóiratban. E cikk egyes elemei ennek felhasználásával készültek.

\section{ÖSSZEFOGLALÓ}

A technológiai fejlődés sebessége exponenciálissá vált napjainkra. A könnyen és általánosan elérhető digitális világ, az információ megosztásán alapuló társadalmi viszonyok gyökeresen változtatták meg az innováció és a fejlesztés irányát. A Szilikon-völgy sikertörténetei sokakat ösztökélnek az ötleteik vállalkozás - startup - formában történő megvalósítására. Az iparágakba is beszivárgó változások mögött gyakran e két alkotóelem áll. A pénzügyi szektorban megjelentek a fintech cégek olyan igényekre reagálva, amelyekre a pénzügyi szolgáltatók a méretükből vagy a szabályozói oldal (érthető) szigora miatt nem tudtak. Lassan, de biztosan hasonló cégek jelennek meg a biztosítási piacon is. Cikkemben arra keresem a választ, hogy van-e már most igény a piacon a szolgáltatásaikra a fogyasztók körében. Felméréssel vizsgáltam a fogyasztók igényét, majd empirikus úton igyekeztem elemezni az eredményeket. Igény pedig - mint a vizsgálatból is látszott - van.

\section{SUMMARY}

The technological development and innovation is growing exponentially during these days. Digital world is within an arm's length and smart gadgets are available for almost everyone. Society depends more on sharing information rather than personal relationships. The growing online sales and number of applications used for buying products are showing the new direction of commerce: Digital. The financial sector is facing new challenges due to the disruptive technologies which has been introduced by new FinTech companies which could respond faster than traditional institutions. In my article I focused on the customer side of the insurance value chain. With a questionnaire I gathered data to be analyzed with empirical methods. My main goal was to show whether there is a need for these technologies already or it is just a hype. My conclusion is: There is a need.
Kulcsszavak: insurtech, fintech, technológia, biztosítás

Keywords: InsurTech, FinTech, technology, insurance

JEL: G19, G22, M13, O33

DOI: $10.18530 /$ BK.2017.4.60

http://dx.doi.org/1018530/BK.2017.4.60

\section{Háttér}

A minap bejelentette az Egyesült Arab Emirátusok minisztere, hogy a centenáriumi évükre komoly elörelépést szeretnének elérni a mesterséges intelligencia területén. A Dubaj 2071 program több pillérre épül: az ún. smart-government, a mesterséges intelligencia és a technológia lesz az emírségek új alapköve. Nyugaton is kiemelt hangsúlyt kapnak az úítások. Szintén nemrégiben szerepelt a hírekben, ahogy a South Park címü rajzfilm megtréfálta az Amazon virtuális asszisztensét (Alexa) alkalmazó felhasználókat. (Nem várt tételt tett a bevásárlólistára, beállított mindenkinek reggel 7 órára egy ébresztést.)

Cikkem témájához közelítve: okosotthon megoldás például a telefonról vezérelhető fütés, elektromosság (nincs több bedugva felejtett vasaló!) vagy akár az alkalmazással öndiagnosztikát végző mosógép. A mérőóra azonnali (real-time) adatokat küld a szolgáltatónak, aki elegendő adat birtokában képes pontosan előre jelezni a fogyasztók igényeit. Az eddig említett fejlesztések már nem is számítanak sci-finek.

\section{A növekvő adatigény látható trend a hagyományosan is \\ adatvezérelt iparágakon (a biztosítás tipikusan ilyen) kívül is.}

Mi is az insurtech? Ez a divatszó állandóan felbukkan a nemzetközi sajtóban. Többnyire a fintech, blockchain, big data szavak kíséretében található, és hol fogyasztói élményről, hol a biztosító háttérterületét megújító technológiai újításról szól. Innen ered maga a kifejezés: az insurance technology szavakból rövidített elnevezés. A kutatásomban inkább az előbbire fókuszáltam, hiszen ez az, amiről a szélesebb publikumnak is lehet véleménye. Megjelenhet-e a felforgató, diszruptív technológia olyan konzervatív iparágban, mint a biztosítás? Van-e rá már most fogyasztói igény? Ha van is, hajlandóak-e az ügyfelek az adataikat adni a megváltozott fogyasztói élményért cserébe? A válasz röviden: igen.

A Gazdasági Világfórum idén augusztusban megjelent jelentésében a fintech cégek által teremtett új helyzetről értekeznek (World Economic Forum 2017). Ebben a jelentésben a biztosítók értékláncára nehezedő nyomást említik, mint a fejlődés egyik mozgatórugóját. Ugyanakkor megjegyzik, hogy még mindig nem egyértelmű, hogy ez a nyomás elegendő lesz-e egy alapvető változáshoz. A PwC Globális fintech-felmérése 
(PwC 2016) szintén alátámasztja, hogy jelentős igény van a technológia és a biztosítási piac találkozására. Azonban megjegyzik, hogy ez a szegmens még messze nem érte el azt a méretet, mint az általánosabb pénzügyi szektor.

\section{A felmérésröl}

Cikkemben a PwC-nél készült igényfelmérés eredményeit elemzem. A felmérés elektronikus formában több fórumon jelent meg (a PwC hivatalos csatornáin, e-mailben, LinkedIn-en, Facebookon). A cél az volt, hogy minél több nem kifejezetten biztosítós háttérrel rendelkező kitöltőhöz eljussunk. A válaszadók száma sajnos nem ütötte meg azt a küszöböt, amely alkalmas hosszú távú statisztikai következtetések levonására, azonban biztosan elegendő a lakosság jelenlegi nézeteinek megsejtésére. A felmérés 2017. június 20. és 2017. július 5. között volt kitölthető, ezalatt 108 ember töltötte ki. A kérdőívet bárki kitölthette, akihez eljutott.

A kérdőív több részből tevődött össze. Az első kérdéscsoport demográfiai információkat kért be a kitöltőtől. A második csoport azt feszegette, hogy milyen tapasztalatai vannak eddig a biztosításokkal, tehát milyen termékekkel rendelkezik, rendezett-e már kárt, és ha igen, akkor hogyan. A harmadik kérdéskör arra vonatkozott, hogy mennyire ismeri a különböző technológiai újdonságokat. Arra is kíváncsi voltam, hogy a kitöltők hogy viszonyulnak az adatmegosztás és a biztosítók kapcsolatához. $\mathrm{Az}$ utolsó részben pedig arra kérdeztem rá, hogy mire vágynak a vásárlók az adataikért cserébe.

1. ábra: Nemek szerinti megoszlás a kitöltök között

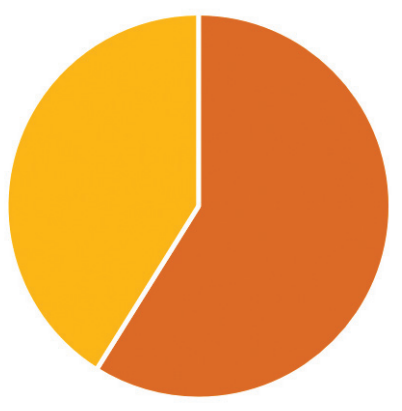

- Nő - Férfi

Forrás: PwC saját gyüjtés

A kérdőívet többségében nők (1. ábra) töltötték ki jellemzően a 26-35 éves korosztályból. A férfi kitöltők között közel azonos volt a 17-25 és a 26-35 év közötti kitöltők aránya (2. ábra).
2. ábra: Kor szerinti megoszlás a nemeken belül

- $17-25-26-35$

-36-45 $=46+$

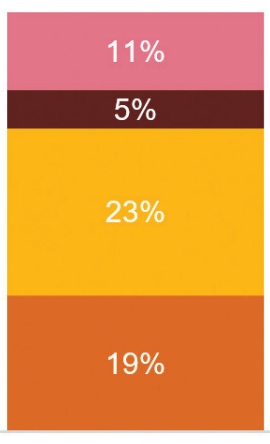

Nő

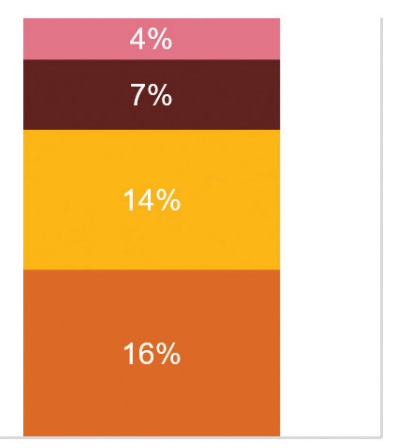

Férfi
Forrás: PwC saját gyüjtés

A biztosítással rendelkezők aránya 3 ágazatban 40 százalék felett volt (3. ábra). Kivételt a casco biztosítás jelentett, amelyet a kitöltők közül jellemzően kevesen vásároltak. Nem meglepő, hiszen a kitöltők átlagos életkora abba az intervallumba esik, ahol általában nem új autót vásárolnak hazánkban.

3. ábra: A kitöltők biztosítási portfóliója

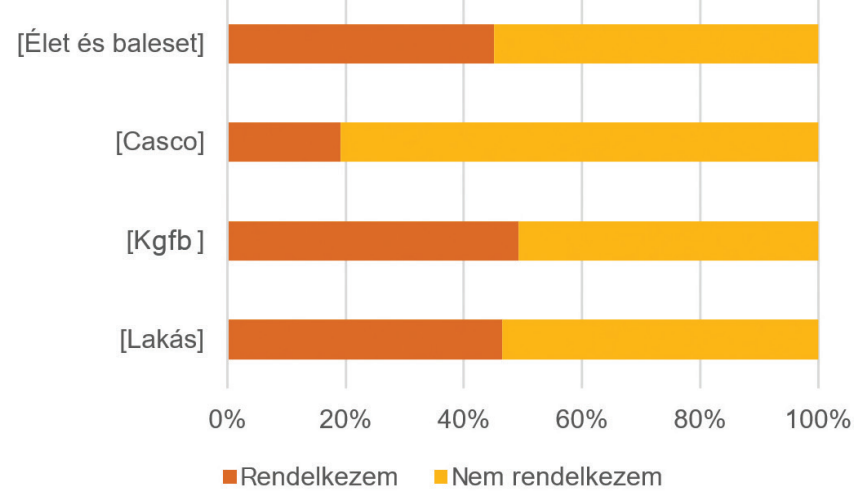

Forrás: PwC saját gyüjtés

A kérdőívben a hagyományosan legalább egy év hosszúságú időtartamra kötött biztosításokat vizsgáltam, a rövid (pl. az utasbiztosítás) nem képezte tárgyát a kutatásnak. Ennek az az oka, hogy abban a szegmensben már most is jelen vannak nem szokványos technológiai megoldások, másrészt rövid távú, alacsony díjért vásárolható 
termékek esetében a vásárlók is rugalmasabban állhatnak a technológiai fejlődéshez. Szintén fontos indikátor volt az, hogy rendezett-e már kárt biztosítónál. A válaszadók csupán 44,4 százaléka válaszolt igennel. A korábban kárt bejelentők 51 százaléka telefonos vagy személyes kárbejelentést tett, 46 százalék papíron jelezte igényét. Érdekesség, hogy 3 százalék már jelentett be applikáción keresztül kárt.

\section{Mit szeretnének a vásárlók?}

A kérdőív összeállításakor fontos szempont volt, hogy a kitöltők jellemzői mellett a preferenciáikat is jobban megismerjem. Személyes beszélgetések alkalmával többször is felmerült, hogy annak ellenére, hogy gond nélkül osztanak meg magukról adatokat (képek geotaggel, vásárolt árut boltmegjelöléssel, napi viseletet, hangulatot), az mégis fontos, hogy ki az, akinek tudatosan adják meg ezeket az információkat.

A preferenciáik feltárásához a jelenlegi szokásaikat is vizsgálni kellett. Hol vásárolnak most? Használnak-e alkalmazásokat, online fizetési megoldásokat? Ismerik-e a technológiai újításokat?

\section{A válaszokból az látható, hogy az internetes bankkártyás \\ fizetés, valamint a webáruházak használata közel áll \\ a fogyasztókhoz, viszont telefonos alkalmazásokon \\ keresztül már jellemzően kevésbé szeretnek vásárolni.}

4. ábra: Jellemzően hogyan vásárolnak?

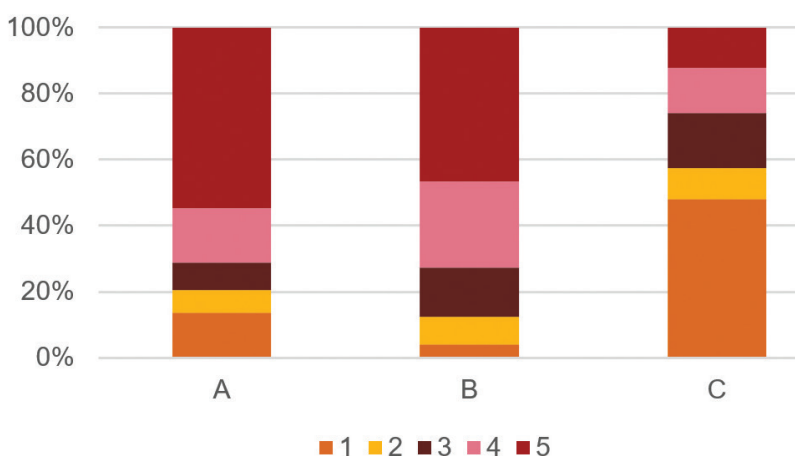

Forrás: PwC saját gyüjtés
A kitöltőket arra kértem, hogy 1-5-ig terjedő skálán jellemezzék, hogy mennyire igaz rájuk (1: semennyire, 5: teljesen):

A. Vásárolnak online bankkártyával.

B. Vásárolnak általában az interneten.

C. Telefonos alkalmazáson keresztül vásárolnak.

Az ábrán a felsorolásnak megfelelő sorrendben ábrázoltam a kapott eredményeket (4. ábra). Míg az első két opciót a kitöltők több mint 70 százaléka érzi igaznak magára nézve, utóbbit csak közel 40 százalékuk.

A technológiai ismereteik is nagyban befolyásolják, hogy mit mennyire szívesen használnának a biztosítottak. A blockchain és a PSD 2 két olyan terület, amely kevésbé a fogyasztókat, jellemzően inkább a vállalkozásokat érinti, az okostelefon, az otthoni okoseszközök és a fitneszóra azonban a várt ismertséget hozta. Azért kerültek bele a felmérésbe, mert mindkét technológia a vállalkozások átláthatóságát, hatékonyságát növeli, ami kárrendezés esetén számíthat a fogyasztói élmény szempontjából. A telematika, ami a gfb és casco biztosításokat forradalmasíthatja, viszont a vártnál kevésbé volt ismert, pusztán a kitöltők 10 százaléka jelezte, hogy találkozott már a fogalommal.

5. ábra: A kitöltök technológiai ismeretei
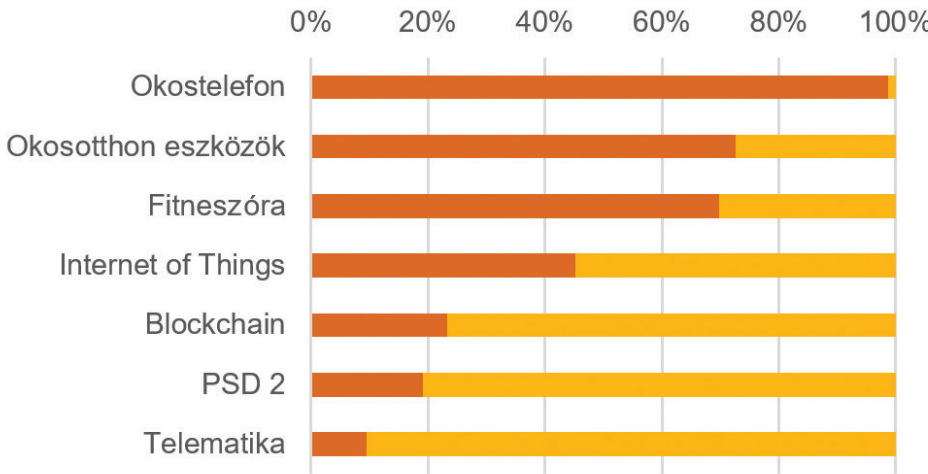

- Ismerem -Nem ismerem

Forrás: PwC saját gyüjtés

A technológiai ismeretekkel egybevágott, hogy a vásárlók jellemzően az okostelefon és a fitneszóra adatait engednék át a biztosítónak. Voltak olyan válaszadók is, akiket nem zavart, hogy az autójuk adatokat rögzít, annak megosztása viszont már nem volt ínyükre. 
A fejezet címében feltett kérdésemre pedig mindezek ismeretében válaszolok. A fogyasztók az adataik megosztásáért általában olcsóbb díjat, jobban személyre szabott termékeket vártak. Nem meglepő módon az adatgyüjtést az okostelefonok és a fitneszórák által rögzítettek közül engednék.

A válaszadók közel 65 százaléka semmilyen formában nem engedné az adatgyüjtést.

\section{Ami igazán érdekes volt, hogy a többség (70\%) \\ nem tartotta drágának a biztosításokat, általában \\ a személyre szabott termékeket hiányolták.}

\section{Hogyan tovább?}

A Világgazdaság című lapban megjelent rövidebb cikkemben is utaltam nemzetközi példákra: az Allianz-X, Kamet olyan megoldások, ahol a biztosítók igyekeztek startupokat finanszírozni, amelyek a technológiai fejlesztéseket végezték nekik.

A legfontosabb tényező továbbra is a fogyasztó. A felhasználói élmény új megoldásokkal való jobbá tétele jelentősen fogja befolyásolni a megtartási képességet. Az igény érezhetően megvan a piacon (még kis mintán is jól látszik), a bizalom azonban hiányzik.

A nem vizsgált terület a biztosítói háttérfolyamatok technológiai fejlesztése. Kár- és kockázatfelméréshez például kiválóan alkalmazható a dróntechnológia. Nagy ipari létesítmények magasan lévő vagy nehezen elérhető pontjai is könnyen vizsgálhatók. A drón üzemeltetése csökkentheti a vállalat ezzel kapcsolatos költségeit (helyszíni szemle gyorsabb kivitelezése, könnyű dokumentálás, egyszerű felderítés). A képfelismerő alkalmazások egyszerű káresetek rendezésében tudnak segíteni: például egy autótörést lefényképez a szerződő, alkalmazással feltölti a biztosítónak, a képfelismerő szoftver elemzi a látható sérüléseket, és rövid időn belül visszajelez, akár a kárt is fizeti. A kárrendezési folyamat felgyorsulása pozitívan hathat a biztosító eredményére.

Mindent egybevetve, hiszek a technológiában rejlő lehetőségekben, úgy gondolom, hogy ez jelenti az iparág jövőjét. Ugyanakkor rengeteg munka vár még mindenkire, hogy ez valóssággá váljon. A szükséges adatmennyiség rendelkezésre áll, csak meg kell szerezni és jól kell használni. Úgy hiszem, hogy az előbbi lényegesen nehezebb lesz, de nem lehetetlen.

\section{IRODALOMJEGYZÉK}

PwC. 2016 „Opportunities Await: How InsurTech is reshaping insurance https://www.pwc.com/sg/en/publications/assets/insurtech-2016.pd

Letöltve 2017.11.14

World Economic Forum. 2017 Beyond Fintech: How the Successes and Failures of New Entrants Are Reshaping The Financial

http://www3.weforum_org/docs/Beyond_Fintech___A_Pragmatic_Assessment_of_Disruptive_Potential_in_Financial_Services.pdf Letöltve 2017.11.14 